\title{
Students' Perceptions of Online Mathematics Learning and Its Relationship Towards Their Achievement
}

\author{
Nuril Huda ${ }^{1, *}$, Tutik Sri Wahyuni ${ }^{2}$,Fida Dinar Fauziyah ${ }^{3}$ \\ ${ }^{1,3}$ Universitas Islam Negeri Maulana Malik Ibrahim Malang, Indonesia \\ ${ }^{2}$ Institut Agama Islam Negeri Tulungagung, Indonesia \\ ${ }^{*}$ Corresponding author. Email: nurilhuda26@uin-malang.ac.id
}

\begin{abstract}
To decrease the level of the spread of the corona virus, the government requires students to study from home. Therefore, it is important to conduct research to determine students' perceptions of online learning. The objectives of this study were (1) to describe students' perceptions of online mathematics learning, and (2) to determine the relationship between students' perceptions and mathematics learning achievement in online learning. This type of research is ex post facto with a quantitative approach. The population of this study were 216 students of class X Mathematics and Natural Sciences (MIPA) at State Madrasah Aliyah (MAN) 1 Trenggalek, while the research sample was 88 students who were taken by simple random sampling. Data collection techniques using questionnaires and tests. In online learning the platforms used are youtube, whatsapp group, and google classroom. Data analysis techniques used descriptive statistics and product moment correlation. The results of this study showed that (1) as many as $73(82.95 \%)$ students have a good perception of online mathematics learning using youtube, 2) there is a relationship between students' perceptions and learning achievement of 0.679 or $67.9 \%$ with a significance of 0.01 . This means that there is a positive relationship between students' perceptions and learning achievement.
\end{abstract}

Keywords: students' perceptions, online learning, mathematics, achievement

\section{INTRODUCTION}

In December 2019, a new virus case emerged in Wuhan, China, namely the corona virus (2019-nCov) and better known as COVID-19. This epidemic attacks the human immune and respiratory systems. This virus is growing very fast. The prevalence and mortality rates continue to increase over time. In early March 2020, this virus was detected to have entered Indonesian territory. Some preventive efforts can be done by maintaining cleanliness, washing hands frequently with soap and hand sanitizer and also physical distancing. Taking into account these conditions, the Indonesian government issued a policy to decrease the spread numbers of Covid19 , including by establishing health protocols, enforcing social distancing, physical distancing, to PSBB (LargeScale Social Restrictions). All elements of society are required to comply with all regulations that have been made. In fact, some routine activities usually carried out by the community must be temporarily stopped in order to decrease the spread of the virus. This situation greatly impacts various areas of life, including in the field of education.
Educational activities which are included as a premiere for the community cannot just be stopped. The solution used to continue learning without direct interaction is by distance learning. During the emergency period of the spread of Coronavirus Disease (COVID19), Minister of Education and Culture releases the Circular Number 4 of 2020 concerning the implementation of educational policies that to decrease the spread level of the corona virus, the government requires students from Pre-School to Higher Education levels to learn from home (BDR). Face-to-face learning involving many people gathered in one room is considered not to apply social distancing and physical distancing rules. Some of the learning models from home recommended by the minister of education and culture are project-based learning, offline learning, home visit methods, integrated curriculum, blended learning and online learning.

Online learning has occurred almost worldwide during the COVID-19 pandemic [1]. Teachers and students as essential elements in teaching are required to undertake the distance education. With the existence of 
online education, it requires all elements of education to adapt to new circumstances. Online learning is carried out effectively by involving educators and students even though they are in different places [2]. Teachers are required to conctruct the active classes even without direct interaction, while students are required to be active in learning activities and understand the material presented indirectly as usual.

In online learning activities, the most important thing needed is the readiness of educators / teachers and students to interact online by utilizing existing technologies. The current condition is urgent for innovation and adaptation related to the use of available technology to support the learning process [3]. Online learning is defined as a knowledge transfer experience using video, audio, images, text communication, software and with internet network support. Some platforms in applications, websites, social networks and Learning Management Systems (LMS) can be used to support online learning activities [4].

Infrastructure that supports free online learning through various discussion rooms such as Google Classroom, WhatsApp, Smart Class, Zenius, Quipper and Microsoft [5]. WhatsApp features include Whatsapp Group which can be used to send text messages, images, videos and files in various formats to all members [6]. Google Classroom also allows teachers and students to develop innovative learning. Face-to-face discussions are like meeting can be done by using various free teleconference video platforms such as Zoom and Google Meet. The platform allows teachers and students to meet and interact virtually with instant message facilities and presentation activities [7]. These various services can be used in accordance with the learning model carried out, such as discussions, presentations, and assignments. For example, Whatsapp Group can be used for a light discussion by having an opinion through sending messages, pictures, voice messages, to videos. If you need a face to face discussion like meeting in person, Google Meet and Zoom can be used for video or audio conference. In addition, the provision of learning materials can also be conveyed by using videos on youtube to using e-modules and so on. After that, learning activities definitely require evaluation which is usually done by giving independent assignments to written tests. Platforms that can support independent assignment activities to a place for collection are like Google Classroom. Meanwhile, online services that can be used to evaluate learning in the form of tests are questionnaire platforms such as Google Form, Kahoot, Quizziz, and so on.

The online learning services used must be in accordance with the online learning model carried out by the teacher. It is intended that the online service function is fully utilized to fully support learning activities, so that learning materials can be conveyed properly and effectively. This is also done at MAN 1 Trenggalek, especially in Mathematics with interest. Based on the results of an interview with one of the Mathematics Interests subject teachers class $\mathrm{X}$ Mathematics and Natural Sciences at MAN 1 Trenggalek in mid-March 2020 , the online learning process on vector material was carried out using several platforms including YouTube, Whatsapp Group, and Google Form. The teacher does not make the video himself directly but looks for videos that are already on YouTube that suitable to the teaching material. Whatsapp group for discussion or strengthening related to teaching materials that do not understand. Google Form for a means of evaluating learning achievement. With this online learning system, it is necessary to have students' perceptions in mathematics online learning.

Perception is the process of receiving stimuli (objects, qualities, relationships between symptoms, and events) until the stimuli are realized and understood [8]. According to the Big Indonesian Dictionary (KBBI), perception is a response or direct acceptance or absorption, or the process of someone knowing things through their five senses. Perception measurement needs to be done to find out the response, acceptance or views of a certain community or group on something. The response became an evaluation material and reference material in order to improve the online learning process in Mathematics of Interest at MAN 1 Trenggalek. Various students' perceptions about mathematics will have an impact on mathematics learning achievement [9].

Learning achievement are the level of success obtained by students after participating in a learning activity characterized by values [10]. Learning is not only memorizing, remembering, but learning is meant to be how a person is able to develop himself based on his perception of what he is learning, the environment and the society where he is [11]. In this pandemic era, where learning activities are carried out online, learning achievement will determine the extent to which students have succeeded in participation in online learning activities which in fact are new to them. Learning models and platforms used to support the learning process have an effect on the learning achievement. Likewise with the results of learning mathematics which is one of the compulsory subjects. So far, mathematics is often assessed as a scary subject. So in times of this pandemic, mathematics must be supported by a suitable and appropriate platform in learning activities to make it more attractively and can support students learning achievement.

Several studies have shown the effectiveness of online learning on several research variables, including students' learning achievement. There was the relationship between students' perceptions and mathematics learning achievement for fifth grade students of SDN-1 Menteng for the 2019/2020 academic 
year [12]. It was obtained that the product moment correlation result with $\mathrm{r}$-count was 0.92 greater than the r-table value of 0.349 . Other research with the title the effectiveness of online learning using online media during the Covid-19 pandemic in mathematics at SMA Negeri 1 Wajo showed that the online media that most students like are Google Classroom 53\% and WhatsApp Group 21\% [13]. Google Classroom application which was proven to increase learning achievement from precycle the number of students who reached Minimum Completeness Criteria were $14(48 \%)$ students to 19 $(66 \%)$ in cycle 1 and to $25(89 \%)$ students [14]. There was effect of using youtube video learning media on mathematical learning achievement in tenth grade students State Vocational High School 2 Sukoharjo in the 2017/2018 Academic Year [15].

Based on the description above, this study aims are to describe students' perceptions of online mathematics learning and determine whether there is a relationship between students' perceptions and mathematics learning achievement in online learning.

\section{RESEARCH METHOD}

This study used the ex post-facto method with a quantitative approach, namely to analyze the relationship between the observed variables without giving any treatment to the existing variables. The population of this research is the students of class X Mathematics and Natural Sciences (MIPA) at MAN 1 Trenggalek with the number of 216 students. The sample technique used is simple random sampling with random classes obtained $\mathrm{X}$ MIPA 2, X MIPA 4 and X MIPA 6, with the number of 88 students. This research was conducted in April - June 2020. The data collection technique used a questionnaire and test method. Questionnaire with a Likert scale consisted of 25 items to explore students' perceptions with 4 options, consist of very agree, agree, disagree, and very disagree. To measure the students' learning achievement on vector material used the test consisted of
20 multiple choice questions. In online learning the platforms used are youtube, whatsapp group, and google classroom. The data analysis technique used descriptive statistics and product moment correlation. The criteria for students' perceptions on the results of this study are as follows (modification of Permendikbud Number 81A 2013).

Table 1. Criteria for Student Perception (SP)

\begin{tabular}{|c|c|}
\hline Interval Score & Criteria \\
\hline $82 \leq \mathrm{SP} \leq 100$ & Very good \\
\hline $63 \leq \mathrm{SP} \leq 81$ & Good \\
\hline $44 \leq \mathrm{SP} \leq 62$ & Sufficient \\
\hline $25 \leq \mathrm{SP} \leq 43$ & Less \\
\hline
\end{tabular}

\section{RESULTS AND DISCUSSIONS}

Mathematics is a compulsory subject that is taught from elementary school to senior high school degrees. Students have various perceptions of mathematics lesson so that it is also related to the way they learn and deal with mathematics problems. Students' perceptions of mathematics are the way students perceive mathematics subjects. This study describes students' perceptions of mathematics in MAN 1 Trenggalek during online learning with the recapitulation presented in Table 2.

Table 2 shows that the number of students who have perceptions of learning mathematics with very good criteria is 7 students with a percentage of $7.95 \%$; Good criteria were 73 students with a percentage of $82.95 \%$ and sufficient criteria were 8 students with a percentage of $9.10 \%$. Based on these results, it can be seen that most of the students of class X MIPA MAN 1 Trenggalek have a good perception of learning mathematics which is done online using youtube. The details of the results of the students' perception questionnaire are shown in Table 3.

Table 2. Recapitulation of Student Perceptions

\begin{tabular}{|c|c|c|c|}
\hline Interval Score & Criteria & Frequency & Percentage \\
\hline $82 \leq \mathrm{SP} \leq 100$ & Very good & 7 & $7,95 \%$ \\
\hline $63 \leq \mathrm{SP} \leq 81$ & Good & 73 & $82,95 \%$ \\
\hline $44 \leq \mathrm{SP} \leq 62$ & Sufficient & 8 & $9,10 \%$ \\
\hline $25 \leq \mathrm{SP} \leq 43$ & Less & 0 & 0 \\
\hline
\end{tabular}


Table 3. Details of Students' Perception Questionnaire Results

\begin{tabular}{|c|c|c|c|c|c|}
\hline \multirow[t]{3}{*}{ Items } & \multirow[t]{3}{*}{ Statements } & \multicolumn{4}{|c|}{ Score } \\
\hline & & 1 & 2 & 3 & 4 \\
\hline & & \multicolumn{4}{|c|}{ Frequency } \\
\hline 1 & I can understand the mathematics material given by the teacher very well $(+)$ & 0 & 23 & 58 & 7 \\
\hline 2 & I can understand math material given by the teacher quickly (+) & 0 & 49 & 30 & 9 \\
\hline 3 & I can only partially understand the mathematics material given by the teacher $(+)$ & 0 & 10 & 62 & 16 \\
\hline 4 & I can understand math material but at the next meeting I forgot (-) & 5 & 48 & 33 & 2 \\
\hline 5 & I can receive the mathematics material given by the teacher by listening (-) & 6 & 46 & 25 & 11 \\
\hline 6 & Mathematics given by the teacher, I accept it clearly (+) & 0 & 22 & 54 & 12 \\
\hline 7 & I received mathematics lesson material clearly but easily lost (-) & 3 & 51 & 31 & 3 \\
\hline 8 & Mathematics is difficult subject (-) & 8 & 46 & 32 & 2 \\
\hline 9 & Mathematics is an interesting subject $(+)$ & 0 & 30 & 49 & 9 \\
\hline 10 & By mastering mathematics, the opportunity to understand other subject matter will be easier $(+)$ & 0 & 8 & 64 & 16 \\
\hline 11 & I have more difficulty learning math than my classmates (-) & 1 & 34 & 52 & 1 \\
\hline 12 & Math lessons made me uncomfortable (-) & 1 & 9 & 74 & 4 \\
\hline 13 & Math is scary, because counting goes on (-) & 2 & 18 & 56 & 12 \\
\hline 14 & Mathematics causes stress (sadness) (-) & 2 & 23 & 53 & 10 \\
\hline 15 & Mathematics is useless in everyday life (-) & 0 & 2 & 61 & 25 \\
\hline 16 & Math subjects cause headaches or dizziness (-) & 2 & 50 & 34 & 2 \\
\hline 17 & Mathematical material has a relationship between one chapter and another $(+)$ & 0 & 0 & 69 & 19 \\
\hline 18 & Mathematical knowledge is useful for solving various problems $(+)$ & 0 & 0 & 68 & 20 \\
\hline 19 & Mathematics trains me to be able to think more carefully and carefully $(+)$ & 0 & 6 & 55 & 27 \\
\hline 20 & Mathematics trains me to be able to think logically and rationally (make sense) $(+)$ & 0 & 7 & 52 & 29 \\
\hline 21 & I understand mathematics as a whole or completely (+) & 1 & 43 & 34 & 10 \\
\hline 22 & Math has trained me to be patient $(+)$ & 0 & 10 & 49 & 29 \\
\hline 23 & Mathematics subject that I understand applied in everyday life (+) & 0 & 15 & 66 & 7 \\
\hline 24 & $\begin{array}{l}\text { When the teacher provides math material, I note important things such as formulas or problem } \\
\text { solving }(+)\end{array}$ & 1 & 5 & 61 & 21 \\
\hline 25 & I do assignments from the teacher independently (+) & 2 & 22 & 53 & 11 \\
\hline
\end{tabular}

Based on Table 3. The results of student responses showed that $46(52.27 \%)$ students disagree that mathematics material can be understood quickly; 48 $(54.55 \%)$ students agree when the next meeting has forgotten the mathematics material that has been taught; $51(57.95 \%) \%)$ students agree that mathematics material has been accepted but is easily lost; $56(63.64 \%)$ students do not agree that mathematics material is scary, because it keeps counting; $46(52.27 \%)$ students agree that mathematics material is difficult; $50(56,82 \%)$ students agree that mathematics material causes dizziness; 43 $(48.86 \%)$ students do not agree that students understand the material completely, $66(75 \%)$ students agree that mathematics material that is understood can be applied in everyday life.
The findings of this study indicate that online learning requires adaptation for students, and teachers are no exception. Item number 1,2 and 21 show that 58 $(65.91 \%)$ students can understand mathematics well but $46(52.27 \%)$ students are not able to understand the material quickly and as many as $43(48.86 \%)$ students not able to understand the material completely. This fact shows that with the same time allocation between faceto-face learning and online learning, it turns out that the process of understanding material in online learning takes a longer time. In discussion forums conducted via chat on whatsapp groups, it takes time to read and shift some of the chats from teachers and students then understand the discussion. In addition, the limitations of understanding the discussion of practice questions in the form of 
pictures, it takes time for students to understand step by step solving the questions independently, in contrast to learning in class the teacher can explain the steps of solving sample questions verbally.

Furthermore, items number 4 and 7 indicate that students tend to easily forget the mathematics material that has been learned even though in the previous meeting they have been able to understand it. This fact shows that it is important for students and teachers to recall (rememorize) short term memory and increase its retention to long term memory. Short term memory is a storage place for information that is consciously processed or thought of by someone, while long term memory is a permanent memory storage area with an unlimited capacity, consisting of networks, schemata, and images and the information is encoded from working memory [16]. The results of these items are in line with students' perceptions on item number 17 as many as 69 $(78.41 \%)$ students agree that mathematics has a relationship between one chapter and another, so that a good understanding of the previous material is very useful for understanding the material in the next chapter hierarchically.

Students' perceptions on item number 13 were 56 (63.64\%) students did not agree that math material was scary, because it kept counting, and item number 8 was $46(52.27 \%)$ students agreed that math material was difficult, and item number 16 as many as $50(56.82 \%)$ students agreed that mathematics material causes dizziness. This fact is in accordance with the results of research which proved that some students argue that mathematics is a difficult subject so that mathematics is the scourge of learning in the classroom which ultimately affects the interaction of the teaching and learning process [17]. Each student has various initial perceptions of mathematics so that they form various attitudes. There are those who have high attitudes towards mathematics subjects, but some others feel phobia or fear or not interested in mathematics because of their learning experiences.

In item number $23,66(75 \%)$ students agreed that mathematics material that was understood could be applied in everyday life. This fact shows that some students already have the perception that some applications in everyday life involve mathematical concepts. For example, the vector concept is applied when an airplane flies and lands, when a boat crosses a river, when children play seesaw, and so on.

In general, students who have perceptions of mathematics lessons well, it is possible to have good /high mathematics learning achievement, and vice versa, students who have bad perceptions of mathematics, may have low or below average learning achievement. Learning achievement are influenced by internal and external factors. Internal factors are factors comes from within individuals who are related to body and spirit, for example, namely mathematical communication skills and students' perceptions of mathematics subjects. The results of learning mathematics vector material consisting of 20 items that have been tested to students of class X Mathematics and Natural Sciences at MAN 1 Trenggalek obtained the lowest score of 25 , the highest of 85 , the average of 53.24 and the standard deviation of 13.90. A recapitulation of learning achievement with the Minimum Completeness Criteria (KKM) is presented in Table 4.

Table 4. Recapitulation of Learning Achievement (LA)

\begin{tabular}{|c|c|c|c|}
\hline Score Interval & Criteria & Frequency & Percentage \\
\hline $70 \leq \mathrm{LA}$ & Pass the Minimum Completeness Criteria & 12 & $13,64 \%$ \\
\hline $\mathrm{LA}<70$ & Not Pass the Minimum Completeness Criteria & 76 & $86,36 \%$ \\
\hline
\end{tabular}

Table 4. Shows that as many as $12(13.64 \%)$ students scored above the Minimum Completeness Criteria and 76 $(86.36 \%)$ students scored below the Minimum Completeness Criteria. Among the students who scored below the Minimum Completeness Criteria, there were 45 students whose scores were below the class average score. After analyzing the question indicators, most students had difficulty solving problems with the question indicators determining the orthogonal projection of the vector, determining the projection of the scalar vector, and calculating the multiplication of the cross product. In 2 questions with indicators determining the vector orthogonal projection, only 21 (23.86\%) students and $16(18.18 \%)$ students out of 88 students were able to answer correctly. In addition, in the questions with indicators determining scalar vector projections, only $26(26.14 \%)$ students were able to answer correctly, while on the indicator calculating the multiplication result of cross products, only $8(9.09 \%)$ students were able to answer true and on this question the 
smallest one that can answer it correctly. The students' responses after the test were 1) insufficient time duration, 2) difficult signals, 3) students were not familiar with the problem solving type or the Higher Order Thinking Skills (HOTS) level. This shows that students must be trained to solve problems with the type of problem solving and HOTS with a certain time allocation and students are able to complete a number of questions. The research result shows that in implementing distance learning using online learning during pandemic period, there are several dimensions that must be considered. They are the teaching material or teaching mode, students interaction, and the learning atmosphere [18].

Online learning during the Covid-19 pandemic that was carried out at MAN 1 Trenggalek on mathematics subjects, especially in vector material, the material and sample questions distributed were in the form of a YouTube link that was already available. Furthermore, students can access the material by online. The teaching material presented in online learning must also be able to meet ideal criteria for students including content that suits student needs, systematic teaching material that makes it easier for students to learn it, and the use of clear vocabulary and writing styles so that easy for students to understand [18]. In this case, the material that is distributed is obtained from material that is already available on YouTube. It is possible that not all of the material expected on the learning indicators can be available on YouTube, unless educators also make their own material. In addition, examples of problem solving and HOTS types of exercises have not been discussed in the learning videos so that students have difficulty in facing the questions given. The discussion session was carried out using the WhatsApp group and assignment collection was carried out using Google Classroom. This platform was chosen with the consideration of ease of access for students, especially with regard to internet signals and quotas, considering that most of Trenggalek Regency is mountainous.
Furthermore, the results of the statistical analysis of the correlation between students' perceptions of mathematics online learning and their achievement obtained data in Table 5.

Based on Table 5, the relationship between student perceptions and learning achievement is 0.679 or $67.9 \%$ with a significance of 0.01 . These results prove that there is a positive relationship between students' perceptions and their achievement. Students who have good perceptions of mathematics subjects in online learning also get good learning achievement. The findings of previous research concluded that there was a positive and significant relationship between students' perceptions of mathematics and mathematics learning achievement in class X MA NU Nurul Huda Mangkang Semarang [19]. This is evidenced by obtaining $\mathrm{r}$-count $=0.712$. Supported by the research which concluded that there was a significant relationship between students' perceptions of mathematics learning and their achievement in fifth class students of SDN-1 Menteng Palangka Raya for the 2019/2020 academic year with the calculation of the coefficient of determination $(\mathrm{rxy})^{2} \mathrm{x}$ $100=86.49 \%$ [12]. In contrast to the research which is found that there was nothing significant between the mean score of students' perceptions in mathematics learning and their learning achievement and there was no opinion between the perceptions of male and female students on mathematics learning [20]. Although the value of students' perceptions on mathematics learning is in the very good category, it does not mean that students' mathematics learning achievement are also good. In addition, the quality of learning is an important aspect in providing effective learning. Effective learning does not only depend on the skills and competencies of the lecturers, but also on the[21] overall learning strategy used [21]. Thus, the quality of learning from various dimensions that consist of planning, implementation and evaluation of learning must be considered and well prepared in order to create effective learning.

Table 5. Correlation Between Students' Perceptions of Online Learning in Mathematics and Learning Achievement

\begin{tabular}{|c|c|r|r|}
\hline & & Students' Perception & Students' achievement \\
\hline Students' Perception & Pearson Correlation & 1 & $.679^{* *}$ \\
\hline & Sig. (2-tailed) & & .000 \\
\hline & $\mathrm{N}$ & 88 & 88 \\
\hline Students' achievement & Pearson Correlation & $.679^{* *}$ & 1 \\
\hline & Sig. (2-tailed) & .000 & 88 \\
\hline
\end{tabular}

\footnotetext{
**Correlation is significant at the 0.01 level (2-tailed).
} 


\section{CONCLUSIONS}

Based on the results of research that has been carried out, it shows that (1) as many as $73(82.95 \%)$ students of class X Mathematics and Natural Sciences at MAN 1 Trenggalek have a good perception of learning mathematics which is carried out online using youtube, and (2) there is a relationship between students' perceptions and their learning achievement of 0.679 or $67.9 \%$ with a significance of 0.01 . This means that there is a positive relationship between student perceptions and learning achievement. Students who have good perceptions of mathematics in online learning also get good learning achievement.

\section{RECOMMENDATIONS}

In online learning during the Covid-19 pandemic, teachers should make learning materials, both in the form of videos and e-modules independently, because the one who knows the needs of students in school is the teacher concerned. In addition, teachers should increase interaction between students and create an atmosphere of active learning. Likewise, students also need to increase their sense of responsibility and independence in learning.

\section{ACKNOWLEDGMENTS}

This research is supported by Mr. Rizky Suga Pratama, S.Pd as mathematics teacher at MAN 1 Trenggalek who helped in collecting the data of this research.

\section{REFERENCES}

[1] K. Goldschmidt, "The COVID-19 Pandemic: Technology use to Support the Wellbeing of Children," J. Pediatric. Nursing., vol. 53, pp. 8890, Jul. 2020, doi: 10.1016/j.pedn.2020.04.013.

[2] U. Verawardina, L. Asnur, A. L. Lubis, Y. Hendriyani, D. Ramadhani, I. P. Dewi, R. Darni, T. J. Betri, W. Susanti, T. Sriwahyuni, "Reviewing Online Learning Facing the Covid-19 Outbreak", Journal of Talent Development and Excellence, vol. 12, no. 3, pp. 385-392, 2020.

[3] S. Ahmed, M. Shehata, and M. Hassanien, "Emerging Faculty Needs for Enhancing Student Engagement on a Virtual Platform," MedEdPublish, vol. 9, no. 1, 2020, doi: 10.15694/mep.2020.000075.1.

[4] Gunawan, N. M. Y. Suranti, Fathoroni, "Variations of Models and Learning Platforms for Prospective Teachers During the COVID-19 Pandemic Period,"
Indonesian Journal of Teacher Education, vol. 1, no. 2, pp. 61-70, 2020.

[5] A. Abidah, H. N. Hidaayatullaah, R. M. Simamora, D. Fehabutar, and L. Mutakinati, "The Impact of Covid-19 to Indonesian Education and Its Relation to the Philosophy of 'Merdeka Belajar,'" Studies in Philosophy of Science and Education, vol. 1, no. 1, p. $38-49,2020$.

[6] J. W. Kusuma, "Perbandingan Hasil Belajar Matematika Dengan Penggunaan Platform Whatsapp Group Dan Webinar Zoom Dalam Pembelajaran Jarak Jauh Pada Masa Pandemik Covid 19", Jurnal Ilmiah Pendidikan Matematika. vol. 5, no. 1, p. 97-106, 2020.

[7] T. Wiranda and M. Adri, "Rancang Bangun Aplikasi Modul Pembelajaran Teknologi Wan Berbasis Android", VOTEKNIKA (Vocational Teknik Elektronika Dan Informatika), vol. 7, no. 4, p. 85-92, 2019.

[8] Irwanto, H. Elia, A. Hadisoepadma, R. Priyani, Y. B. Wismanto, C. Fernands, Psikologi Umum. Jakarta: Gramedia Pustaka Utama, 1991.

[9] I. D. Saputra and A. Syafik, "Pengaruh Persepsi Terhadap Prestasi Belajar Matematika Siswa Kelas VIII SMP/MTs Se-Kecamatan Gombong Kabupaten Kebumen", Ekuivalen, vol. 21, No. 2, p. 104-107, 2016.

[10] Dimyati, Mudjiono, Belajar dan Pembelajaran. Jakarta: Rineka Cipta, 2009.

[11] D. S. Prawiradilaga, Wawasan Teknologi Pendidikan. Jakarta: Kencana Prenada Media Group, 2012.

[12] M. Y. Meidya, "Hubungan Persepsi Siswa Terhadap Mata Pelajaran Matematika Dengan Hasil Belajar Matematika Siswa Kelas V SDN-1 Menteng Tahun Ajaran 2019/2020". Skripsi, Universitas Palangkaraya Fakultas Keguruan Dan Ilmu Pendidikan Jurusan Ilmu Pendidikan Progran Studi Pendidikan Guru Sekolah Dasar, Palangkaraya, 2020.

[13] Mustakim, "Efektivitas Pembelajaran Daring Menggunakan Media Online Selama Pandemi Covid-19 Pada Mata Pelajaran Matematika," Al Asma: Journal of Islam Education., vol. 2, no. 1, pp. $1-12,2020$.

[14] Y. Darmawan, "Penggunaan Aplikasi Google Classroom Dalam Upaya Meningkatkan Hasil Belajar Matematika Pada Siswa Kelas X Ips 3 Sma Batik 2 Surakarta", Skripsi, Universitas 
Muhammadiyah Surakarta Fakultas Keguruan Dan Ilmu Pendidikan: Program Studi Pendidikan Matematika, Surakarta, 2019.

[15] R. Pambudi and A. Afghohani, "Pengaruh Media Video Youtube Terhadap Prestasi Belajar Matematika Pada Siswa Kelas X SMK Negeri 2 Sukoharjo Tahun Ajaran 2017/2018, Jurnal Pendidikan, vol. 28, no. 2, p. 175-182, 2019.

[16] I. Hitipeuw, Belajar dan Pembelajaran. Malang: Universitas Negeri Malang, 2009.

[17] Y. Purnomo, "Pengaruh Sikap Siswa pada Pelajaran Matematika dan Kemandirian Belajar Siswa terhadap Prestasi Belajar Matematika," JKPM Jurnal Kajan Pendidikan Matematika, vol. 2, no. 1, pp. 93-105, 2016, doi: 10.30998/jkpm.v2i1.1897.

[18] S. Zuriati and B. Briando, "Persepsi Siswa terhadap Pembelajaran Online di Masa Pandemi pada Sekolah Menengah Atas Negeri Empat Tanjungpinang. Presented at Webinar dan Call for Papers 'Menyongsong Era Merdeka Belajar,” p. 15, 2020.
[19] Widayani, "Hubungan Antara Persepsi Peserta Didik Pada Mata Pelajaran Matematika Dengan Hasil Belajar Matematika Kelas X MA NU Nurul Huda Mangkang Semarang," Skripsi, IAIN Walisongo Semarang Fakultas Ilmu Tarbiyah dan Keguruan: Program Studi Tadris Matematika, Semarang, 2011.

[20] N. A. Ahmad, F. L. Azizan, N. F. Rahim, N. H. Jaya, N. M. Shaipullah, and E. S. Siaw, "Relationship between Students' Perception toward the Teaching and Learning Methods of Mathematics' Lecturer and Their Achievement in Pre-University Studies," Internasional Education Studies, vol. 10, no. 11, p. 129-134, Oct. 2017, doi: 10.5539/ies.v10n11p129.

[21] A. Lizzio, K. Wilson, and R. Simons, "University Students' Perceptions of the Learning Environment and Academic Outcomes: Implications for theory and practice," Studies in High Education., vol. 27, no. 1, pp. 27-52, Feb. 2002, doi: 10.1080/03075070120099359. 